\title{
CONTEXT- AND BELIEF-RELATED ASPECTS OF ESTONIAN RIDDLES
}

\author{
Piret Voolaid \\ Senior Research Fellow \\ Department of Folkloristics \\ Estonian Literary Museum \\ e-mail: piret.voolaid@folklore.ee
}

\begin{abstract}
This article studies the belief-related context (of use) of Estonian riddles. The study is based on archival records dating back to the end of the nineteenth and beginning of the twentieth centuries, which are concerned with solving riddles and primarily reflect the way that people in a peasant society thought. In addition to the studies that focus on texts of regular riddles (e.g. dealing with poetics or geographical dispersion), this paper discusses the beliefrelated functions of riddles that have been minimised during cultural changes. The study gives consideration to links between Estonian archival material and archaic mythological riddle forms (neck-riddles, kennings), taboos and restrictions related to solving riddles as well as to combinations of belief-related backgrounds with playful and entertaining aspects. Belief-related backgrounds are confirmed by the syncretic relation of riddle solving to everyday tasks (e.g. solving riddles in the autumn and winter periods as part of calendar traditions, riddles in marriage proposals and wedding traditions), which reveal connections to both sacral and profane changes of time, including economy; on occasion, solving riddles served to ensure personal luck and to promote one's household and work.
\end{abstract}

Keywords: belief aspects of riddling, context of riddles, Estonian riddles, neck riddles

\section{INTRODUCTION}

Riddles as a separate research topic have been studied in Estonia since the 1990s. One of the principal responsibilities of the working group for short forms, which used to operate at the Institute of the Estonian Language and in 2000 continued under the Department of Folkloristics of the Estonian Literary Museum, was the digitalisation of traditional (or proper) riddles and compilation of the publication Eesti mõistatused (Estonian riddles) (EM 2001, 2002) in the scholarly series on Estonian folklore, Monumenta Estoniae Antiquae, and an online database comprising 100,000 texts (Krikmann \& Krikmann 2012). 
The most important theoretical studies on Estonian traditional riddles are approaches to genre issues, papers on the geographical distribution of riddles, and the part dedicated to riddles in Arvo Krikmann's study Sissevaateid folkloori lühivormidesse (Insights into short forms of folklore) (Krikmann 1997) and his lecture material (Krikmann 2000), a four-part monograph on the sources of Estonian riddles (Saukas 2005a, 2005b, 2007, 2009), and an analysis of what makes riddles sound good (Sarv 2003).

The scarce and rather random records on the traditional use of Estonian riddles, typical riddle solving situations, etc., dating back to the final quarter of the nineteenth century, indicate that riddles once had a wide social and cultural background in Estonia. Riddles have not been used by children alone, and their function has not merely been that of entertainment; they have also been related to a wider view on the world (see Oinas 1984: 162; Viidalepp 2004: 70). This notion is confirmed by observations on riddle material from several other nations. In her studies, Annikki Kaivola-Bregenhøj (1996: 10-16, 2001: 92-127) analyses the contexts of both traditional riddles and riddle jokes, and describes them through social situations and culture. She views riddles as an enigmatic verbal genre and observes them in the social relations of jokes and entertainment as a so-called icebreaker in tense situations, and as a means for creating and strengthening the atmosphere of eroticism. Cultural context plays an exceptionally significant role in the cognitive process of riddles. The ambiguity that is characteristic of riddles can be so empirical and culture-specific that outsiders have no way of understanding it (Kaivola-Bregenhøj 1996: 14), but it can also be important in the socialisation process of related parties (McDowell 1979: 223-226; Abrahams 1968: 155, etc.) and express ritual unity.

In this article I will focus on the contextual archival material of riddles and draw on about 500 archival records to analyse the social backgrounds that have supported the process of solving riddles, and study the way that those social backgrounds have entwined with belief-related backgrounds. The study focuses on the issue of belief-driven objectives and meanings of riddles. I will take a close look at the known functions of older, so-called traditional or proper or classical Estonian riddles (magical-religious functions, use of riddles in ritual and playful contexts, etc.) that distinctly oppose several principal functions (entertainment, social criticism) of the newer riddle material.

\section{ARCHAIC FORMS - NECK RIDDLES AND KENNINGS}

Archaic forms of riddles have played an important part in mythological texts. It has been said that the sacred or dangerous nature of riddles is reflected in that in mythological or ritual texts they nearly always appear as so-called neck 
riddles or capital riddles, which must be solved as a matter of life or death, as the player's life is at stake (Huizinga 1949: 108).

Archer Taylor (1951: 1) believes that neck riddles are truly hard nuts to crack for people to whom they are posed as they narrate an event known only to the poser of the riddle. Seemingly impossible riddles were posed, for example, to people who had been sentenced to death, thereby presenting them with a chance to save their neck from the noose by solving such riddles. The birth of riddles with a similar function, known all over the world, dates back to the creation of mythologies of a number of nations across the world. One of the most archaic neck riddles (or capital riddles) is the so-called riddle of the Sphinx, which originates from the story of King Oedipus as told in the mythology of ancient Greece: What creature goes on four feet in the morning, on two at noonday, on three in the evening? Man. In childhood he creeps on hands and feet; in manhood he walks erect; in old age he helps himself with a staff (Hamilton 1942: 257). The logical distribution of this riddle should be from myth (folklore) to literature, but the internationally known riddle motif probably originates from Sophocles' tragedy and not directly from the myth (Lill 2004: 251). In Estonian archival material the same riddle is represented in 249 records from various regions, and has been classified as type No. 263 in the academic publication of Estonian riddles: Four legs in the morning, two by noon, and three by night? A human (EM 2001: 261). There are no records of this riddle type in Estonian archival material in relation to its mythological context or its being presented in a narrative, but similar functions can also be seen in Estonian riddle stories. The 'neck riddle subject' is directly represented in the stories registered under No. 927 in the Tale Type Index (ATU) that was created by Antti Aarne, improved by Stith Thompson, and later on by the German folktale scholar Hans-Jörg Uther. The scheme of the riddle type known as 'Out-Riddling the Judge' (ATU 927) is as follows: The accused is set free when the judge cannot solve the riddle propounded to him by the condemned person (by a relative of the condemned). The riddle refers to extraordinary or accidental events that happened to the person setting the riddle, and thus is unsolvable for outsiders. There are also records in the Estonian Folklore Archives, in which the hero of the story must come up with the right answer to a question to either escape from imprisonment or save their own life or the lives of their loved ones (see Voolaid 2005: 36-38).

The sacral and religious-mythological background of riddles and their solving is also implied in the Old Norse Poetic Edda, written down in the ninth to tenth centuries, in the form of metonymic-metaphorical circumlocutions that are based on kenning-like tropes and have been used, among other things, as euphemisms for mythological creatures, kings, warriors, women, body parts, ships, weapons, 
the sea, and gold, as well as in relation to battlefields and hunting (Kuusi 1992: 107). Estonian chain riddles also consist of kennings ${ }^{1}$, but there is no proof of the existence of any genetic relations between Old Norse kennings and Estonian kenning-like writings (Virtanen 1966: 14). The Exeter Book, which dates back to approximately the same period, the tenth century, features an impressive collection of riddles - 95 Old English riddles in verse form; through their use of imagery and symbolism, they can be treated as manifestations of Anglo-Saxon sacral knowledge and have inspired researchers to reconstruct Anglo-Saxon sacral history (Alexander 1982 [1980]; Williamson 1977).

\section{THE MAGICAL SEMANTIC FIELD OF RIDDLING IN AUTUMN AND WINTER}

In the work calendar of Estonian peasants, riddles constituted a part of the autumn and winter periods, when the end of threshing and flax processing marked the start of indoor jobs in the winter season; women of the household started with handicraft while men headed out to chop wood and haul it out of the forest (Hiiemäe 1994: 5). The end of the 'economic' year of farming left enough time to celebrate this and to ensure good crops for the coming year. In his 1965 dissertation Richard Viidalepp also pointed out that the stories told at twilight in the autumn and wintertime often entailed solving riddles, and that telling stories and riddling at twilight has been thought to have caused or promoted something (Viidalepp 2004: 70). According to archival records, solving riddles served as a magical act that was supposed to affect next year's crops. It was also linked to the variety of the most important element of peasant societies - the food. Folk belief assumed a riddling habit to keep the food on the table or, to put it more poetically, 'to keep the spoons from getting lost'. People's diet quite literally depended on the well-being of domestic animals, which was thought to be in correlation with riddling. Felix Oinas (1984: 166) has highlighted the strict regulations regarding the posing of riddles - it was not permitted to solve riddles in the late-winter season when there were young animals in the barn, because it was thought to hinder their growth and development. Estonians as well as other nations regarded riddles as spells that could enhance or harm the growth of animals and crops.

Significant folk calendar celebrations in the autumn and winter seasons in Estonia include St. Martin's Day and St. Catherine's Day (10 and 25 November respectively) with their rich belief-related backgrounds. The tradition of celebrating the eve of the holidays by going out and visiting other households dressed, accordingly, as mardisant (Martinmas mummer) or kadrisant 
Figure 1. Virve Murumaa is writing down riddles from Juhan Rääk in Simuna Nursing Home. Photograph by Ülo Tedre 1950 .

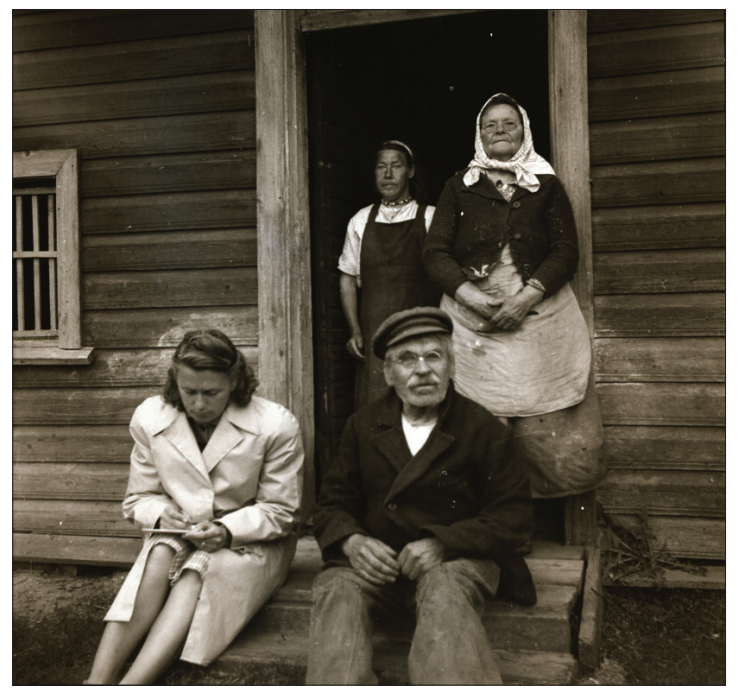

(St. Catherine's Day mummer) is still known today. Archival records present documented cases of the use of riddles in the peasant culture in dialogues between Martinmas mummers and the families they visited (Hiiemäe 1994: 68-71), and it can be argued that the folklore repertoire of the mummers who celebrate the holidays today and did so in the last decades of the twentieth century includes traditional as well as more recent types of riddles. For example, folklorist Mare Kõiva has described the mummers who visited her family in 1992 (RKM II 461, 439-452) as well as the folklore they used.

She recorded the performance of five groups of mardisandid and two groups of kadrisandid. The communication of two groups of mardisandid and both groups of kadrisandid also featured riddles, which were posed to the family (altogether 27 riddles), but the family also tested the knowledge of the mardisandid and kadrisandid in the dialogue that ensued. I can recall from the experience of my own family that on St. Martin's Day in 2003 our house was visited by a group of mummers who were complete strangers to us, and who took some papers out of their bag after their performance of traditional St. Martin's Day songs to test the family's knowledge on droodles collected and published by folklorists. This kind of a riddle-dialogue creates opportunities for communication with the family. In the age of smart devices, contemporary mummers use smartphones to read out texts. Therefore, riddles have performed a belief-laden and communication-enhancing role in traditional celebrations of St. Martin's Day and St. Catherine's Day (see also Voolaid 2005: 44). The mummers in modern microdistricts, which are comprised of multi-storey apartment buildings, are usually unknown to the family, and riddles are a good neutral way to help reduce the awkward tension for visitors as well as the family who is being visited. 


\section{RIDDLES IN MARRIAGE PROPOSALS AND WEDDING TRADITIONS}

In archaic neck riddles an incorrect answer to a riddle could mean that you had to give up your life, but according to records collected from people, correct/ incorrect answers could also affect a person's future in traditions surrounding marriage proposals and weddings. Parents of brides-to-be were said to have warded off unwanted suitors from the family by giving them complicated riddles just as in fairy tales. This is illustrated by the following record taken down by Mall Proodel (Hiiemäe) in 1956.

When a young man came to propose, the girl's parents gave him a riddle to solve. If he gave the right answer, the marriage proposal was a success, but if he was 'at a loss' and displayed his stupidity, the proposal was not accepted and the suitor had to try his luck in another household. If the girl's parents found the suitor to be suitable, they gave him an easier riddle to solve. Pauliine Kiver explains that it remains unclear whether this practice was followed in these parts during the twentieth century, but it was commonplace at the end of the nineteenth century.

RKM II 61, 55 < Iisaku, Mäetaguse

Riddles were part of the wedding tradition in which the bride distributed the contents of the dowry chest to the guests. This was followed by promises of presents from the latter (Tedre 1973: 87). The people giving the 'gifts' were primarily close family and other relatives, and the promises were metaphorical or humorous. So the father-in-law gave to the bride 'a meadow to cut six times a week' (i.e. cleaning the house), and the sister-in-law gave her 'carrying poles to share and bucket yokes in twain' (i.e. tending the animals). Gifts also included a 'pole stallion' (cat), 'a ship that sales the wind and seven fathoms of silken string' (cradle and napkins), 'a meadow to cut four times a year' (sheep), 'a harrow that harrows backwards' (chicken), 'a plot for a strawberry bed and myself to pick them for the day' (promise to become a godparent), 'a hat for the moon and a wreath for the sun' (a hat if it is a son and a coif if it is a daughter), etc. The following note by Daniel Pruhl from 1894 gives us an idea of the wedding customs:

Once the gifts had been handed out and the process of giving money was finished, the best man started to order a gift for the newlyweds. Saying something like: 'Here we have two birds about to build their nest and we should aid them in doing so'. Whoever wanted to give a gift then stepped forth and made a promise and was given a beer or a drink and a blessing as well. The gift was not revealed directly, but referred to in riddles so 
that the person giving a cradle would say 'I'll give you a boat', and the person giving a beehive would refer to a barrel full of shocks. A dozen child's rags or half tissues, a chicken that works backwards; a child's hat, an uncovered head is unseemly; a child's coat, small children look lovelier with a coat; a foal, for the first son to ride to church; a calf, who shall be the milker or the ploughman. A sheep to undress four times a year, etc. Some also said: I'll give you a sheep, I'll give you a cow, meaning I'll give you a 'wagon'; some young men also said they'll give a wedding to the young couple, or 'a wedding returned'. And so, most wedding guests gave this and that and each person tried to find the best words for their gifts - the funnier the better.

E $5167<$ Haljala Parish

According to Estonian folklorist Ülo Tedre, there were never any wedding gifts at all, except for the bride's dowry and the donations made by the godparents (ibid.: 88).

\section{'PUNISHING' THOSE UNABLE TO SOLVE RIDDLES}

The social functions of the riddling genre are also highlighted in a number of riddling games, which include a more archaic and belief-related game from Finland, called 'Going to Hymylä' (hölmölän matka - 'a trip to Stupidville'2), whereby the person unable to solve the riddle was sent, by using Kalevala-metre verses, to Hyvölä, Himola, Hölmölä, Huikkola, or Hymylä (Virtanen 1977: 80, 1984: 77; Kaivola-Bregenhøj 2001). There are a handful of records of such acts from Viru County, the southern region of Tartu County, and from Võru County. The game meant that respondents who were unable to guess a certain number of riddles would become the laughing stock, and would be sent someplace far away in verse form to 'look' for the answers.

There is a report from Kadrina Parish in Viru County, sent by Johannes Sõster in 1910, according to which anyone who was unable to solve a riddle was sent to Üiküla; based on the report by Armilda Hallik, they were sent to Uikkala:

In the past it was fashionable to solve riddles. When two to three people got together, they started riddling. Whoever was unable to solve seven riddles was sent to uikkala: Uih, aih, uikkala, put his leg on the doorknob and shat five barrelfuls. Whoever fails to solve the riddles has to eat it. ERA II 166, 241 (17) < Iisaku Parish (1937)

We can quite safely assume that 'uikkala' refers to a small village in Ida-Viru County called Uikala (see Voolaid 2017: 121). We can probably draw parallels 
with the Finnish riddling game because both Üiküla and Uikala as place names in Estonia seem to be Finnish loans (compare to Huikkola, which has a similar sound). Sending people who struggle to solve riddles some place to retrieve the right answers has made the act of posing riddles more playful and ritual. The sequence of sending people away employs long verse forms using alliteration and assonance and fantasies (probably conjured up 'on the spot') about what will happen to a slow-witted respondent.

In the southern region of Tartu County (e.g. in the parishes of Võnnu, Kanepi, Sangaste, Otepää, Maarja-Magdaleena, Urvaste, Setu, Vastseliina, and TartuMaarja) it was common to send people who could not solve riddles to Rasina. The writings do not specify why it was namely Rasina. But we do know that the village of Rasina is one of the oldest in the Mooste municipality in Võnnu Parish and was first mentioned in the records of the Bishopric of Dorpat under the name Rassinal in 1403; Rasin Manor was first mentioned in 1611 (EE 1995: 37). The village is located on a crossroads of gravel roads leading to Mooste (about 8 km from Rasina) as well as Tartu (ca. 40 km), Räpina (ca. 18 km), and Ahja. There are a total of 20 reports from the period from 1895 to 1992 about being sent to Rasina. The earliest of these from Jakob Hurt's correspondents date back to 1888 :

Those unable to solve the riddles shall be sent to the old hag in Rasina to retrieve the answers. Take the brake as your horse, the mortar as your carriage, the dog's tail as your stick, the cat's tail as a whip, two scones made of chicken shit, and go away to Rasina. An old hag in Rasina was putting bread in the oven and her daughter looked over the fire; their little dog in the yarn basket on top of the oven started to bark. The old hag said to her daughter: 'Go see who is coming, the dog is barking.' The daughter then went to see and said: 'There's a man / woman there with his / her wits about her.'After that the person asking the riddles enters, greets them and starts explaining the riddles.

H III 11, 491 < Kanepi, Johann Väggi

Timo Leisiö (2000: 273-283), a Finnish music anthropologist, has observed the historic spread of this archaic phenomenon across Finland and interpreted this game as part of a shamanistic practice, finding that this post-shamanistic game of riddles grew out of a plausible ritual. Hymylä and other place names in the game originally symbolised a kind of underworld / other side where the shaman would go using supernatural powers to get answers needed in his society (this world) (ibid.: 284). It is probably no coincidence that John R. R. Tolkien, who was an expert on Anglo-Saxon language and mythology, included the concept of ancient and sacred riddles in his Hobbit tale (Tolkien 2006 [1937]: 81-105). In the riddling game between hobbit Bilbo Baggins and Gollum, the former 
wins by cheating (asking as his final question: 'What has it got in its pocket?') and as a result his opponent must act as his guide.

According to Savely Senderovich (2005: 59-64, 118), riddles in their archaic form are based on the following paired mechanisms: explicit and implicit, manifest and latent, innocuous and taboo, common and esoteric, and declared and silently implied. Ana Stefanova (2007: 134) has employed Émile Durkheim's (1915) theory of anthropological rituals to the study of riddles, dividing the world into sacral (holy) and profane (secular), which can be defined through their polarising nature. The level of questions and experiences in sacral and profane riddles is fundamentally different. In the first case, the riddle is surrounded with a conscious supernatural, ritual or symbolic meaning. Profane riddles, on the other hand, lack the ritual (religious or ceremonial) environment and highlight the 'concealed' meaning; the questions are routine in meaning and presented in a colloquial manner. There is a discrepancy between the conscious and unconscious in profane riddles. Tatiana Vladykina (1998: 42) has studied the syncretism of calendar rituals at greater length and has shown how riddles are used to describe the ways of constructing the world. In the Udmurt folk calendar, riddling takes place during the transition period from the old year into the new, and relates to the alternation of sacral and profane periods. The solving of riddles stimulates wisdom and the physical strength of people in the magically hazardous transition period.

Psychoanalyst Albert Rapp has stated that any kind of riddling is a 'mental duel' and that there are records of riddling competitions in history, bets relating to riddles, etc. Battles of wits were originally not regarded as entertainment - it was one of those more humane and refined forms of duelling that people used to establish their hierarchical relations; a sharp and witty mind was also more useful for survival in natural selection (Rapp 1951: 21). Popular modern-day quiz shows (e.g. Who Wants to Be a Millionaire, Jeopardy, Are You Smarter Than a 5th-Grader?) are closely related to the mental duels comprising questions and answers. Every adult can apply to take part in television shows. Giving correct answers to different questions may help improve the players' financial situation, but it is also a great way to stand out with your wits (or dim-wittedness) in front of a wider public and market your personal brand. Different quiz show formats have helped popularise a number of Estonian so-called media personalities (e.g. Hardi Tiidus, Valdo Pant, Toomas Uba, Hillar Palamets, Indrek Salis, Jevgeni Nurmla, and others). Therefore, it is not accidental that the Estonian public has had great interest in television competitions testing the wisdom of politicians, which are organised, for example, before general elections (e.g., the party quiz show held on the national channel, Estonian Television, on 23 February 2011 drew in an audience of 120,000 people (TNS Emor, TV Audience Meter Survey, period 23 February 2011)). 


\section{RIDDLING AS A FORBIDDEN AND DISGRACED ACTIVITY}

It is curious that the records on riddling in Estonian archival material are very contradictory. On the one hand, it was as if compulsory for peasants to pose and solve riddles in the darker autumn and winter seasons to ensure the availability of food and the well-being of cattle, but on the other hand, based on some records, riddles have also been condemned - riddling has been considered as a sin and it has been related to evil forces as is illustrated by a record written down by August Voldemar Kõrv, dating from 1925.

A farm hand said that it was not allowed to solve riddles because it was supposed to be a sin. Once upon a time, when people were solving riddles, a bloody hand fell to the ground and told the people there to riddle it.

E, StK 27, 123 (4) < Koeru

'Bloody hand' motifs such as this make up quite a distinct type of legend, i.e., a merger of a belief/viewpoint and the 'confirming' narrative.

There are certain types or archival records that give testimony about riddles as something that is often considered inappropriate and depreciative, and such records can be summed up in a proverb-like report taken down by Aleksandra Grünvald-Univer in Karksi Parish in 1936: 'Riddles are said to be like the Lord's Prayer for the Old Nick' (ERA II 138, 459 [5]). Records related to this topic reveal hints of a pejorative attitude towards riddles and posing them. On the basis of these records, riddling seems to be something of a medium between the real world on the Earth and supernatural satanic forces, a tool that can summon evil entities from the spirit world, e.g. the Old Nick. This is claimed by Jakob Ploompuu and Hans Rebane from Kuusalu Parish (dated 1892) and Kristjan Põldmäe from Jüri Parish (dated 1895) in their letters to Jakob Hurt:

No good is said to come from riddling too much at a time because it is said to attract the Old Nick. That is why people are reluctant to talk about riddles and old customs.

Once upon a time, two women were riddling in a little sauna in the woods long into the night. All of a sudden a big black finger appeared from under the floor and a gruff voice called out: 'Riddle me, riddle me!' The women took fright and never told riddles again.

(This is probably why it is difficult to get lore, and especially riddles, from people, as this might attract Old Nick's servants. Throughout centuries, Christian teaching has implanted thoughts into people's minds that it is a sin.)

H II 40, 442/3 (4) < Kuusalu Parish 
It was not allowed to tell old tales or riddles in the evening because it was said to cause the fiend to show itself at night. (To scare people.)

H IV 5, 42 (7) < Jüri Parish

The supernatural characters mentioned in these reports include: Old Nick, a fiend, a yellow-faced hag, the Devil, ghosts, and Old Barney. There are even records on the pagan nature of riddles from the not-so-distant past: in 1969, folklorist Pille Kippar wrote down the following record in Rakvere Parish:

It is said that riddles were Old Nick's doing. If someone riddles then Old Nick was said to lurk around the room at night, saying: 'Where's my book, where's my book? What have you been up to with my book?' and that meant that riddling was banned.

KKI 49, 229/30 (23)

There are a couple of dozens of stories that have been written down in the archives, which exemplify riddling as an activity that has occasionally been seen as forbidden and disgraceful. These stories are horror stories by nature. Whereas horror stories are usually characterised by a violation of some sort of a rule/taboo (children going to places that are out of bounds or purchasing forbidden items), the unexpected manifestation of an evil person (thing) in the house or by an item in the house turning evil (Kõiva 1996: 169), the texts with the below stereotypical plot scheme fit the horror genre perfectly. In a simplified form, the structure of these kinds of records is the following. People pose riddles to one another in a dark farmhouse late at night, when all of a sudden a bloody hand, the head of an animal or something else is put through the window or door and a strange voice calls out: 'Riddle me, riddle me!' Of the above characteristics, the stories feature a violation of rules (riddling without permission) as well as an unexpected appearance of an evil thing (a demon, in this case) in the house. Let us take a closer look at some archival records on this subject. In 1895, Johannes Reinthal sent the story below from Rapla Parish to Jakob Hurt:

Once upon a time, children were indoors posing riddles to each other. Then all of a sudden a bloody hand was put through the window and a strange voice called out: 'Riddle me, riddle me!'

H I 7, 122 (13)

As was mentioned above, the prime time for telling folktales and posing riddles in the peasant society was evenings and twilight hours of autumn and winter (see also Viidalepp 2004: 45-54). Pursuant to this notion, dark nights create the best atmosphere for telling these kinds of horror stories. It is the time that the supernatural doorway to the realm of fantasies opens up to the human 
mind in its most vivid and excited imaginary state. Furthermore, the plot of the story is closely linked to the practices of riddling activities during those times, adding even more excitement. The time and place of these stories are defined (on a dark night in the farmhouse), yet their credibility is diminished by the fact that they begin with the indefinite phrase 'once upon a time', much like fairy tales. Just as in the previous report, there are temporal and spatial similarities in the text written down by Johan Reimann in 1896 :

Once upon a time, on a Thursday night, the children were sitting on the floor, posing riddles for one another to solve. All of a sudden the door opened and a big, truly enormous bloody fist appeared in the doorway, and a voice said: 'Riddle me, riddle me!' This scared the children and they stopped riddling, prompting the fist to disappear as well. In some places it is considered a sin to solve riddles on Thursday and Saturday nights and that must be why the Devil showed its fist.

H I 10, 88 (4)

At least in certain regions the Church can be held accountable for the attitude according to which riddling is regarded as a sin. Such a derogatory attitude is evident in the record written down by folklore collector Enda Ennist in 1937.

We didn't do much else here but learned the songs by heart. There were no riddles or other stories like that. God save us from those!

ERA II 159, 494/5 (8) < Ridala

The same idea is expressed by Ilja Daniel's report from 1937:

Riddling was forbidden during church.

ERA II 160, $501(26)<$ Setu

Astra Lauk from Kadrina Parish, a student of Tartu Reaalkool (Tartu Gymnasium of Sciences), also paints a vivid picture of the ban on riddling on Saturdays and the subsequent punishment - appearance of the Devil - in her writing dating from 1939:

But on Saturday nights it was forbidden to tell old stories. On Saturday nights it was customary to go to the sauna, and then afterwards older people started to read the Bible. Children had to sit tight and listen quietly, but when they were feeling mischievous, they all sneaked off to the old threshing room. And then it was time for riddling, Father and Mother wouldn't know. And they started riddling. They went on and on posing riddles to one another. Then, all of a sudden, a black man jumped out and started skipping about on the floor, yelling out: 'Riddle me, riddle me - what am I?' He had horns on his head, a big long tail and hooves 
like horses. This frightened the children and they fled back to the room. They told their parents and were told off, so they went to bed all teary-eyed and promised never to solve riddles again on Saturday nights.

ERA II 240, 551/2 (3)

The location could also be some other place, as is seen in the story written down by Tõnu Wiedemann in 1892:

In the olden days of serfdom, during threshing. Serfs and ghosts posed riddles for one another. This went on for a good while. All of a sudden a red hand appeared through the ceiling. And a voice went: 'Riddle me, riddle me - what is this?' Everyone was too scared to even breathe.

H II 37, 677 (1) < Jõhvi Parish

The personified Devil or the aggressor (Kõiva 1996: 167) in horror stories such as these is usually a scary 'bloody hand' or a 'truly enormous bloody fist'; the colour red (also characteristic of demons) functions here as a symbol of fire (hell), suffering, and blood (Valk 1994: 120). A 'bloody knife' shares the same meaning. But the Devil also appears in the form of a 'big black finger'. The colour black, which symbolises the under-realm and the forces of darkness was seen as the usual colour of demons as early as the beginning of Christianity (ibid.). In some stories we can also see animal forms, such as 'a head of a blazing-red horse' or 'a bloody calf', which are also likely to indicate the Devil.

The educational aspect of the stories is revealed in their climax.

On New Year's Eve young boys and girls all gathered in one household. They poured molten lead for luck and had all kinds of fun. After all that, they finally covered the floor with straw, sat down, and started to pose riddles to one another. In the end two boys went outside. They saw a big yellow-faced old hag standing in the yard, with long teeth like those of a rake in her mouth. 'Riddle me, riddle me!' the old hag shouted through her teeth and disappeared. The boys ran back inside in terror and told the story to the others. After that the boys and girls didn't feel at all like riddling any more.

E 6249-6259 < Ambla, Tapa, Otto Hintzenberg, no date

In the past, when people wanted to pass the time or ward off sleep, they posed riddles for others to solve. Once upon a time there was a family that gathered in their house, posing riddles again. All of a sudden, the door of the house opened and a man appeared on the doorstep, hit his hand against his chest and said: 'Riddle me!' The master of the house happened to be holding a large silver brooch in his hand and used it to hit the man 
at the door. The door was shut right away, but they heard groaning in the porch. The groans finally stopped when the rooster started crowing. E 21772-21773 (9) < Karl August Sinka, Halliste Parish, 1895

The stories recorded in texts from the end of the nineteenth century tend to be more horror-like, but later texts from the second quarter of the twentieth century are more akin to anecdotes. The story written down by Mari Sarv in 1936 is rather humorous in tone.

In the olden times, when people were inside in the evening, solving riddles, Old Nick stuck its tongue through the door and said: 'Hey stupid, riddle me!' The child in the cradle then said: 'That is Old Nick's tongue.' Then it disappeared.

ERA II 142, 409/10 < Karksi Parish

In addition to mystical reasons, there are also some very pragmatic ones for banning riddles, as can be seen in the following text from Karksi Parish.

It is not allowed to solve riddles at night or you won't be able to fall asleep. H II 48, 330 (66) < Karksi Parish, Jaak Hünerson, 1894

The reason for banning riddles at night may be attributed to their stimulating nature because solving riddles provokes the mind, thus deterring sleep as described in the reports below.

Riddles were solved when making yarn, to ward off sleepiness.

RKM II 64, 406 (308) < Hargla Parish, Olga Jõgever, 1957

In the past riddles were told at night while working. During the long winter nights while sitting behind spinning wheels, to ward off sleepiness. RKM II 92, 74 < Kambja Parish, Anna Relli, 1959

It would be interesting to find out more about the usage links and meanings of reports related to the ban on riddles. But again, such comments would require explanatory context. At first, they seem to share similar traits with taboos and bans familiar from routine beliefs (e.g. no whistling indoors), the study of which could benefit from knowledge of belief-related backgrounds.

\section{CONCLUSION}

If riddles are considered through methods of text generation and figurativeness, they can be seen as an aesthetic phenomenon, but when analysing this, it is also important to take into account the context of riddles, not just their textual 
parameters. This will help clarify the more general functions and meanings of riddles. The enigmatic speech genre opens up the belief-related and entertaining relations of the belief (e.g. sending people who do not know the answer to the right place somewhere to get the answers), as 'icebreakers' in tense situations (e.g. celebrations of St. Martin's Day and St. Catherine's Day), as the creator and promoter of an erotic atmosphere. Riddling as a forbidden activity is expressed very strongly in a special type of fictional narratives (horror or warning stories) which were told to amplify the emotion related to the violation of rules (riddling without permission).

Therefore, in social contexts the function of riddles is opened up further (e.g. in syncretic relation with autumn-winter riddling calendar and wedding customs), featuring belief-related backgrounds, sacral and profane passing of time as well as economy - in certain cases, riddles were told to promote the household and work. Belief-related contexts were put in focus in this study, but these are far from being independent and different from other contexts - they combine with other, for instance, social, entertaining, aesthetic, and historic contexts.

\section{ACKNOWLEDGEMENTS}

This article is an English adaptation and expansion of the chapter of the doctoral thesis Eesti mõistatused kui pärimusliik muutuvas kultuurikontekstis (Estonian Riddles as a Folklore Genre in a Changing Cultural Context; see Voolaid 2011a). This research has been supported by the European Regional Development Fund (Centre of Excellence in Estonian Studies - CEES TK145) and is related to research project IUT 22-5 "Narrative and belief aspects of folklore studies" (Estonian Research Council). The author wishes to thank the anonymous reviewers for their valuable comments.

\section{NOTES}

1 EM 1324: A gipsy's pocket watch, a pig's oak, a frog's well, and a cat's apple? Head (sun), alder, spoon, and juniper berry; EM 1509 - Wethers of the valley, sheep of the woods? Wolves and bears; EM 1876: Feathered fox? Raven; EM 2165: Road slip, land reed, rooster of the forest, goat of the sea, a white-headed calf of the beach? A sledge, a harrow, a cuckoo, a fish, foam. See also Voolaid $2011 \mathrm{~b}$ on kenning-like riddle conundrums.

2 In Finnish hölmöläinen means 1. 'nitwit'; 2. 'fool, dumb person'; lä is a locative suffix, and himola < himo - 'passion, desire'. 


\section{ARCHIVAL SOURCES}

Manuscript files of the Estonian Folklore Archives at the Estonian Literary Museum: $\mathrm{H}=$ Folklore collection of Jakob Hurt (1860-1906)

$\mathrm{E}=$ Folklore collection of Matthias Johann Eisen (1880-1934)

E, StK = Folklore collection of Matthias Johann Eisen's grantees (1921-1927)

ERA $=$ Folklore collection of Estonian Folklore Archives (1927-1944)

$\mathrm{KKI}=$ Folklore collection of the Department of Folkloristics of the Institute of Language and Literature (1941-1984)

$\mathrm{RKM}=$ Folklore collection of the Department of Folkloristics at the Estonian Literary Museum (1945-1994)

\section{REFERENCES}

Abrahams, Roger D. 1968. Introductory Remarks to a Rhetorical Theory of Folklore. The Journal of American Folklore, Vol. 81, No. 320, pp. 143-158. http://dx.doi. org/10.2307/537664.

Alexander, Michael 1982 [1980]. Old English Riddles from the Exeter Book. Poetica, Vol. 11. London: Anvil Press Poetry.

ATU = Uther, Hans-Jörg 2004. The Types of International Folktales: A Classification and Bibliography. Part I: Animal Tales, Tales of Magic, Religious Tales, and Realistic Tales, with an Introduction. Folklore Fellows' Communications 284. Helsinki: Suomalainen Tiedeakatemia.

Durkheim, Émile 1915. The Elementary Forms of Religious Life. London: G. Allen \& Unwin. Available at https://archive.org/details/elementaryformso00durk/page/ n6, last accessed on 15 February 2019.

EE 1995 = Eesti entsüklopeedia . [Estonian Encyclopaedia.] Vol. 8, Rai-Sum. Tallinn: Eesti Entsüklopeedia.

EM 2001 = Eesti mõistatused. [Estonian Riddles.] Monumenta Estoniae Antiquae IV. Aenigmata Estonicae I. Comp. by Anne Hussar \& Arvo Krikmann \& Rein Saukas \& Piret Voolaid; edited by Arvo Krikmann \& Rein Saukas. Tartu: Eesti Keele Sihtasutus.

EM 2002 = Eesti mõistatused. [Estonian Riddles.] Monumenta Estoniae Antiquae IV. Aenigmata Estonicae II. Comp. by Anne Hussar \& Arvo Krikmann \& Rein Saukas \& Piret Voolaid; edited by Arvo Krikmann \& Rein Saukas. Tartu: Eesti Keele Sihtasutus.

Hamilton, Edith 1942. Mythology. New York: The New American Library. Available at https://archive.org/details/EdithHamiltonsMythology/, last accessed on 20 March 2019.

Hiiemäe, Mall 1994. Eesti rahvakalender VI. [Estonian Folk Calendar.] Tallinn: Eesti Raamat.

Huizinga, Johan 1949. Homo Ludens: A Study of the Play-Element in Culture. London \& Boston \& Henley: Routledge and Kegan Paul. Available at http://art.yale.edu/ file_columns/0000/1474/homo_ludens_johan_huizinga_routledge_1949_.pdf, last accessed on 15 February 2019. 
Kaivola-Bregenhøj, Annikki 1996. Riddles and Their Use. In: Galit Hasan-Rokem \& David Shulman (eds.) Untying the Knot: On Riddles and Other Enigmatic Modes. New York \& Oxford: Oxford University Press, pp. 10-36.

Kaivola-Bregenhøj, Annikki 2001. Riddles: Perspectives on the Use, Function and Change in a Folklore Genre. Studia Fennica Folkloristica 10. Helsinki: Finnish Literature Society. http://dx.doi.org/10.21435/sff.10.

Kõiva, Mare 1996. Siis astu aknalauale. [Then Step on the Window Sill.] In: Mare Kõiva (ed.) Mängult-päriselt. Tänapäeva folkloorist II. Tartu: Eesti Rahvaluule Arhiiv \& Eesti Keele Instituut, pp. 166-188. Available at http://www.folklore.ee/rl/pubte/ ee/cf/mjap/mare.html, last accessed on 14 February 2019.

Krikmann, Arvo 1997. Sissevaateid folkloori lühivormidesse I: Põhimõisteid, žanrisuhteid, üldprobleeme. [Insights into Short Forms of Folklore I: Basic Terms, Genre Relations, General Problems.] Tartu: Tartu Ülikooli Kirjastus. Available at http://www. folklore.ee/ kriku/PARINTRO/Parintro.pdf, last accessed on 15 February 2019.

Krikmann, Arvo 2000. Eesti mõistatuste kujunditest. [On the Figurativeness of Estonian Riddles.] Available at http://www.folklore.ee/ kriku/PARINTRO/troobid.htm, last accessed on 15 February 2019.

Krikmann, Arvo \& Krikmann, Jaak 2012. Eesti mõistatused. [Estonian Riddles: Database.] Web database. Available at http://www.folklore.ee/moistatused, last accessed on 14 February 2019.

Kuusi, Matti 1992. "Kenning”-jälkiä kalevalaisessa muinasepiikassa? [Traces of Kennings in Kalevala-Meter Epics.] In: Lauri Harvilahti (ed.) Metafora: Ikkuna kieleen, mieleen ja kulttuuriin. Helsinki: Suomalaisen Kirjallisuuden Seura, pp. 107-124.

Leisiö, Timo 2000. The Riddle Game of Visiting Hymylä Revisited: A Shamanic Point of View. In: Maria Vasenkari \& Pasi Enges \& Anna-Leena Siikala (eds.). Telling, Remembering, Interpreting, Guessing: A Festschrift for Prof. Annikki KaivolaBregenhøj on her 60th Birthday 1st February 1999. Joensuu: Suomen Kansantietouden Tutkijain Seura, pp. 272-286.

Lill, Anne 2004. Tragöödialeksikon: Teemad ja tegelased antiikkreeka teatris. [Lexicon of Tragedy: Themes and Characters at Ancient Greece Theatre.] Tartu: Tartu Ülikooli Kirjastus.

McDowell, John Holmes 1979. Children's Riddling. Bloomington \& London: Indiana University Press.

Oinas, Felix J. 1984. Mõista, mõista, mis see on. [Riddle Me, Riddle Me.] In: Felix J. Oinas (comp.) Vargamäe tõde ja õigus: Esseid = Truth and Justice of Vargamäe and Other Essays. Stockholm: Välis-Eesti \& EMP, pp. 162-173.

Rapp, Albert 1951. The Origins of Wit and Humor. New York: Dutton.

Sarv, Mari 2003. Lühivormide heakõlalisuse ehituslikest eeldustest. [Structural Prerequisites for the Euphony of Short Forms.] Uurimusi folkloori lühivormidest. Reetor 1. Tartu: Eesti Kirjandusmuuseum, pp. 145-188.

Saukas, Rein 2005a. Eesti mõistatuste allikalugu. [The Source History of Estonian Riddles.] Vol. I. Reetor 5. Tartu: Eesti Kirjandusmuuseumi folkloristika osakond \& Eesti Kultuuriloo ja Folkloristika Keskus.

Saukas, Rein 2005b. Eesti mõistatuste allikalugu. [The Source History of Estonian Riddles.] Vol. II. Reetor 6. Tartu: Eesti Kirjandusmuuseumi folkloristika osakond \& Eesti Kultuuriloo ja Folkloristika Keskus.

Saukas, Rein 2007. Eesti mõistatuste allikalugu. [The Source History of Estonian Riddles.] Vol. III. Reetor 7. Tartu: EKM Teaduskirjastus. 
Saukas, Rein 2009. Eesti mõistatuste allikalugu. [The Source History of Estonian Riddles.] Vol. IV. Reetor 8. Tartu: EKM Teaduskirjastus.

Senderovich, Savely 2005. The Riddle of the Riddle: A Study of the Folk Riddle's Figurative Nature. London \& New York: Kegan Paul.

Stefanova, Ana 2007. Riddles as a Community Psychological Phenomenon in Folklore: Myths, Fairytales, Personal Literature Art. Folklore: Electronic Journal of Folklore, Vol. 35, pp. 131-142. http://dx.doi.org/10.7592/FEJF2007.35.stefanova.

Taylor, Archer 1951. English Riddles from Oral Tradition. Berkeley \& Los Angeles: University of California Press.

Tedre, Ülo 1973. Eesti pulmad: Lühiülevaade muistsetest kosja- ja pulmakommetest. [Estonian Weddings: Short Overview of Old Estonian Wedding Traditions.] Tallinn: Eesti Raamat.

Tolkien, John Ronald Reuel 2006 [1937]. The Hobbit, or There and Back Again. London: Harper Collins Publishers.

Valk, Ülo 1994. Kurat Euroopa usundiloos: Sissejuhatus demonoloogiasse. [The Devil in European Religion: Introduction into Demonology.] Tallinn: Vikerkaar.

Viidalepp, Richard 2004. Eesti rahvajuttude laadist, funktsioonist ja jutustajatest. [The Style, Function, and Narrators of Estonian Folktales.] Sator 4. Tartu: EKM Teaduskirjastus. Available at http://www.folklore.ee/rl/pubte/ee/sator/sator4/, last accessed on 14 February 2019.

Virtanen, Leea 1966. Suomalais-virolainen arvoitussarja. [Finnish-Estonian Riddle Series.] Suomalaisen Kirjallisuuden Seuran toimituksia 282. Helsinki: Suomalaisen Kirjallisuuden Seura.

Virtanen, Leea 1977. On the Function of Riddles. In: Leea Virtanen \& Annikki KaivolaBregenhøj \& Aarre Nyman (eds.) Arvoitukset: Finnish Riddles. Suomalaisen Kirjallisuuden Seuran toimituksia 330. Helsinki: Suomalaisen Kirjallisuuden Seura, pp. 77-90.

Vladykina, Tatiana 1998. Udmurtskii fol'klor: Problemy zhanrovoi evoliutsii i sistematiki. [Udmurt Folklore: Problems of Genre Evolution and Systematics.] Izhevsk: Udmurtskii Institut istorii, iazyka i literatury UrO RAN.

Voolaid, Piret 2005. Eesti mõistatuste perifeerne aines: Elektroonilised andmebaasid internetis. [The Periphery of Estonian Riddles: Digital Online Databases.] Diss. (Master's Thesis). Tartu: Tartu Ülikool. Available at http://dspace.utlib.ee/dspace/ bitstream/10062/1216/5/voolaid.pdf, last accessed on 15 February 2019.

Voolaid, Piret 2011a. Eesti mõistatused kui pärimusliik muutuvas kultuurikontekstis. [Estonian Riddles as a Folklore Genre in a Changing Cultural Context.] Dissertationes folkloristicae Universitatis Tartuensis 16. Tartu: Tartu Ülikooli Kirjastus. Available at http://dspace.ut.ee/bitstream/handle/10062/17528/voolaid_ piret.pdf, last accessed on 15 February 2019.

Voolaid, Piret 2011b. Why is the Floor Squeaking? Because the Wiser One Gives In: On Relations Between Estonian Conundrums and Paremiology. 4th Interdisciplinary Colloquium on Proverbs: 7th to 14th November 2010: 4 Coloquio Interdisciplinar sobre Proverbios: Actas ICP10 Proceedings, pp. 245-257.

Voolaid, Piret 2017. Mõistatused ja mõistatamine Virumaal. [Guessing and Riddles in Virumaa.] Mäetagused, Vol. 66, pp. 115-138. https//doi.org/10.7592/MT2017.66. voolaid.

Williamson, Craig 1977. The Old English Riddles of the Exeter Book. Chapel Hill: The University of North Carolina Press. 